\title{
IMPLEMENTATION OF COLLAGE SKILLS ON EARLY CHILDHOOD CREATIVITY
}

Tri Saptuti Susiani, Maulida Ajeng Priyatnomo, Laras Tantifah

Universitas Sebelas Maret

maulidaajeng1@gmail.com

Article History

accepted 30/09/2018

approved $12 / 10 / 2018$

published 30/10/2018

\section{Keywords}

Collage, Creativity, Early

Childhood

\begin{abstract}
Creativity is one of the values in character education. But the fact is, according to Yohana (2013: 2) most children's artistic creativity is only extracted through drawing or coloring. Children will surely get bored if they only draw or color, therefore a breakthrough makes creativity through collage skills. The objectives of this study are: 1) Describe what collage skills are 2) Describe the creativity of early childhood; 3) Explain that collage skills can foster early childhood creativity. The method used is literature study which comes from books, literacy, notes, and reports that can be solved. The results of this study are; 1) Description of collage skills; 2) Description of the creativity of early childhood; 3) Collage skills can foster early childhood creativity. The conclusion of this study is that collage skills can foster early childhood creativity.
\end{abstract}

Social, Humanities, and Education Studies (SHEs): Conference Series https://jurnal.uns.ac.id/shes

p-ISSN 2620-9284 e-ISSN 2620-9292 


\section{PENDAHULUAN}

Pendidikan Anak di Usia Dini diadakan bertujuan mewujudkan suasana proses pembelajaran untuk mengembangkan potensi anak secara optimal. Usia lahir sampai dengan 6 tahun adalah usia yang sangat menentukan karakter dan kepribadian seorang anak. Usia itu sangat penting bagi pengembangan pada dirinya. Mereka juga mampu menyerap informasi dengan cepat. Karenanya, perkembangan anak perlu didukung oleh keluarga, sekolah, dan lingkungan sekitarnya supaya tumbuh kembang anak berjalan secara maksimal dan sesuai dengan tahap perkembangannya. Salah satu aspek perkembangan anak yang harus diperhatikan guru untuk ditingkatkan adalah suatu kretivitas.

Kreativitas ialah kemampuan untuk menghasilkan sesuatu karya atau ide yang pada dasarnya menggunakan imajinasi seseorang, serta kemampuan untuk memperoleh pemecahan masalah yang dihadapi dan ide yang mempunyai tujuan tertentu. Karenanya kreativitas perlu ditumbuhkan sejak dini dalam diri anak, sehingga anak dapat menjadi dirinya sendiri dan mampu membuat karya yang menarik sesuai dengan imajinasinya. Pengembangan kreativitas anak dapat dilakukan dengan cara memupuk, merangsang, memberikan kesempatan kepada anak untuk berkarya dan bereksplorasi melalui kegiatan yang menyenangkan dan kreatif seperti pembelajaran kolase. Beberapa karakteristik seperti banyak akal, penuh cipta, tekun, mandiri, dan percaya diri (Ayan dalam Yeni dan Euis, 2011 : 16)

Yohana (2013 : 28) mengatakan bahwa kreativitas seni sangat penting bagi pertumbuhan anak di Usia Dini sebab melalui kreativitas anak mampu menciptakan atau membuahkan hasil karya-karya baru berdasarkan imajinasi dan pemikiran bakat yang dimiliki anak.

Namun, era sekarang pengembangan kreativitas anak kurang bervariatif, seperti yang diunkapkan oleh Yohana (2013 : 2) kreativitas seni anak kebanyakan hanya digali melalui gambar atau mewarnai saja. Anak-anak pasti akan bosan apabila hanya menggambar atau mewarnai, oleh karena itu adanya terobosan membuat kreativitas melalui keterampilan kolase.

Menurut Hajar Pamadhi, dkk (2010 : 5.2) Kolase adalah karya seni rupa dua dimensi yang menggunakan bahan yang banyak macamnya selama bahan dasar yang dimaksud mampu dipadukan dengan bahan dasar lain yang akhirnya dapat menyatu menjadi karya yang utuh dan dapat mewakili ungkapan perasaan estetis orang yang membuatnya.

Menurut penelitian Desi (2014 : 5) kegiatan kolase anak dapat berkreasi sesuai dengan kretivitas masing-masing dan merupakan suatu kegiatan yang akan menarik bagi anak-anak. Anak-anak dapat menempel, menyusun dan merekatkan bahanbahan yang telah tersedia sesuai dengan kreativitas setiap individu.

Adapun penelitian lain dari Irawati (2012 : 12) menyatakan bahwa kreativitas anak dapat meningkat melalui kolase dari daun nangka di TK Azarah Ma'Arif Pariaman.

Hal itulah yang memperkuat kajian tentang keterampilan kolase yang mampu meningkatkan kreativitas pada Anak di Usia Dini. Adapun rumusan masalah paparan di atas ialah : 1). Apakah itu keterampilan kolase? 2). Apakah itu kreativitas anak di Usia Dini? 3). Apakah keterampilan kolase mampu meningkatkan kreativitas pada anak di Usia Dini? Maka, tujuan dari penelitian kajian ini ialah : 1) Deskripsi keterampilan kolase; 2) Deskripsi kreativitas anak di Usia Dini; 3) Keterampilan kolase mampu menumbuhkan kreativitas anak di Usia Dini.

\section{METODE}

Metode yang digunakan dalam penelitian ini menggunakan metode studi kepustakaan. Menurut Nazir (2003) studi kepustakaan merupakan sebuah teknik untuk mengumpulkan data dengan cara melakukan studi penelaahan literatur, buku, laporan, 
dan catatan yang berhubungan dengan masalah yang akan dipecahkan. Dalam hal ini peneliti melakukan kajian yang berkaitan dengan teori yang mendukung topik penelitian, mengumpulkan informasi, dari kepustakaan yang berhubungan.

\section{HASIL DAN PEMBAHASAN}

Pada bagian ini akan dibahas 3 pokok bahasan, yaitu : 1) Deskripsi keterampilan kolase, 2) Deskripsi kreativitas anak di Usia Dini, 3). Keterampilan kolase mampu menumbuhkan kreativitas anak di Usia Dini

\section{1) Keterampilan Kolase}

\section{a. Pengertian Keterampilan (Skill)}

Menurut Suprapto, T (2009 : 135) Skill adalah kemampuan untuk menggunakan akal, fikiran dan ide dan kreatifitas dalam mengerjakan, mengubah ataupun membuat sesuatu menjadi lebih bermakna sehingga menghasilkan sebuah nilai dari hasil pekerjaan tersebut. Ada juga pengertian lain yang mendefinisikan bahwa skill adalah suatu kemampuan untuk menerjemahkan pengetahuan ke dalam praktik sehingga tercapai hasil kerja yang diinginkan. Berikut ini adalah berbagai pendapat tentang skill menurut para ahli, yaitu :

a) Menurut Gordon, skill adalah kemampuan untuk mengoperasikan pekerjaan secara mudah dan cermat.

b) Menurut Nadler, skill kegiatan yang memerlukan praktek atau dapat diartikan sebagai implikasi dari aktifitas.

c) Menurut Higgins, skill adalah kemampuan dalam tindakan dan memenuhi suatu tugas.

d) Menurut Iverson, skill adalah kemampuan untuk melakukan pekerjaan secara mudah dan tepat.

Jika disimpulkan pengertian skill berati kemampuan untuk mengoperasikan suatu pekerjaan secara mudah dan cermat

b. Kolase

\section{a) Pengertian Kolase}

Menurut Sumanto (2006:93) kolase asalnya dari kata Collage Bahasa Perancis yang berarti merekat. Menurut Hajar Pamadhi dan Evan Sukardi (2010: 5.4) kolase adalah karya seni rupa dua dimensi yang menggunakan bahan yang bermacam-macam selama bahan dasar tersebut mampu dipadukan dengan bahan dasar lain yang pada akhirnya mampu menyatu menjadi karya yang utuh dan dapat mewakili ungkapan perasaan estetis orang yang membuatnya.

Menurut (Yohana, 2013:23). "Kolase ialah karya gambar atau desain yang dibuat dari susunan potongan-potongan, batuan-batuan, kaca berwarna, porselin, dalam berkembangnya suatu mozaik, telah memperbanyak keragaman karya seni rupa seperti lukisan dinding (Fresco), karya seni kaligrafi, benda-benda kerajinan tangan, dekorasi, seni bangunan dan lainnya.

Jadi dapat disimpulkan bahwa pengertian kolase ialah suatu karya yang menggunakan bermacam-macam bahan seperti potongan-potongan, batuanbatuan, kaca berwarna, porselin, dan bahan dasar lainnya yang mampu dipadukan satu sama lain. 


\section{b). Contoh-contoh Hasil Karya Kolase}
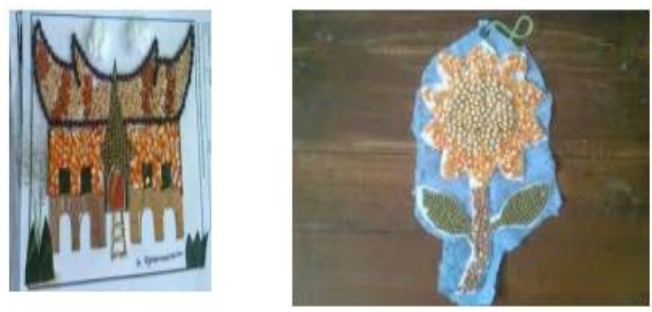

\section{Gambar 1. Kolase Menggunakan Bahan Berbagai Kertas, Kain Perca, Manik-manik, Benang. \\ Sumber :Handayani S, dkk (2018: 3)}

b). 1 Contoh gambar kolase menggunakan bahan olahan berbagai kertas, kain perca, manic-manik, benang.
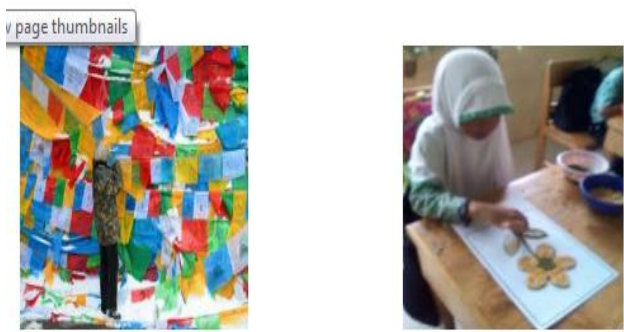

\section{Gambar 2. Kolase Menggunakan Bahan Bekas Seperti Koran Bekas, Kalender Bekas, Majalah Bekas, Bungkus Makanan \\ Sumber : Handayani S, dkk (2018:4)}

b).2 Contoh gambar kolase menggunakan bahan bekas seperti koran bekas, kalender bekas, majalah bekas, bungkus makanan.

\section{c. Manfaat Teknik Kolase}

Menurut Yohana, (2013: 23) ada manfaat kegiatan kolase, yaitu :

a) Dapat Meningkatkan kreativitas seni pada anak

b) Dapat meningkatkan pemahaman anak melalui penglihatan

c) Dapat meningkatkan daya pikir, daya serap, emosi, cita rasa keindahan menempel kolase

\section{2) Kreativitas Anak di Usia Dini}

\section{a. Pengertian Kreativitas}

Kreativitas ialah keterampilan dalam mengenali permasalahan yang tertera, dan kemampuan membuat perencanaan-perencanaan untuk mencari pemecahan masalah yang dilakukan berdasarkan pemikiran dan ide-ide yang dimiliki, (Wasih, 2007:17). Kreativitas ialah kemampuan seseorang untuk melahirkan sesuatu yang baru baik berupa gagasan maupun karya nyata yang relatif berbeda dengan apa yang telah ada sebelumnya (Utami, 2005:26). Menurut Sunarto (2008:24) kreativitas ialah bentuk aktivitas imajinatif yang dapat menghasilkan sesuatu yang sifatnya asli, 
misalnya anak berkhayal merayakan hari ulang tahunnya, maka dengan sendirinya pikiran yang terbayang adalah roti ulang tahun yang cantik.

Jadi dapat disimpulkan bahwa pengertian kreativitas ialah daya kemampuan seseorang yang berbentuk aktivitas imajinatif dan kemampuan membuat perencaan-perencanaan yang mampu menyelesaikan masalah yang ada dengan mengembangkannya atau lebih inovatif.

\section{b. Ciri-Ciri Kreativitas}

Menurut Yohana (2013:22) membagi ciri anak yang dapat mendukung kreativitas ke dalam dua bagian yaitu: ciri bakat (atitude Trait) dan ciri non bakat (non-atitude Trait). Ciri-ciri yang berupa bakat atau atitude trait pada kreativitas (sikap kreatif) seperti kelancaran, kelenturan, keluwesan atau fleksibilitas, dan orisinalitas dalam berfikir, ciri-ciri bakat atau atitude sikap kreatif perlu dikembangkan sejak dini sebagai potensi kreatif yang dimiliki seorang anak agar dapat berkembang optimal. Selain ciri bakat atau atitude, sikap kreatif perlu didukung oleh kematangan pribadi. Beberapa karakteristik pribadi yang sudah teruji dalam penelitian atau kajian ilmiah, memiliki pengaruh yang signifikan terhadap kreativitas adalah rasa ciri non atitude antara lain: percaya diri, keuletan atau daya juang yang tinggi, apresiasi estetik, serta kemandirian.

\section{3). Keterampilan kolase mampu menumbuhkan kreativitas anak di Usia Dini}

Menurut Dewi dalam penelitian skripsinya (2014: 31) Proses pembelajaran melalui kegiatan kolase dapat meningkatkan kreativitas karena pada kegiatan kolase anak dapat berkreasi sesuai dengan kreativitas anak masing-masing dan merupakan kegiatan menarik bagi anak. Anak dapat menempel menyusun dan merekatkan bahan-bahan yang tersedia sesuai dengan kreativitas masing-masing. Melalui kegiatan kolase membantu kemampuan berbahasa anak, anak terlatih unuk menjelaskan atau bercerita tentang hasil karyanya kepada guru. Anak lebih mudah belajar tentang sesuatu bila melalui kegiatan yang menyenangkan seperti kolase. Pada saat kegiatan kolase sama halnya anak sedang bermain, sehingga dalam proses pembelajarannya berlangsung dengan menyenangkan dan dapat meningkatkan kreativitas anak.

Diperkuat oleh gagasan Rachmawati dan Kurniati (2005:52), bahwa dalam mengembangkan kreativitas anak dapat dilakukan melalui kegiatan menciptakan produk (hasta karya) dimana kreativitas anak akan terfasilitasi untuk berkembang dengan baik. Dalam kegiatan hasta karya setiap anak akan menggunakan imajinasinya untuk membuat bentuk suatu bangunan atau benda tertentu sesuai dengan khayalannya. Dalam pembuatannya pun mereka menggunakan berbagai bahan yang berbeda. Pada dasarnya hasil karya anak yang dibuat melalui aktivitas membuat, menyusun atau mengkontruksi ini akan membantu mereka menjadi lebih kreatif. Salah satu kegiatan yang dapat mengembangkan kreativitas seni kolase anak.

Sejalan dengan hasil penelitian di atas, kegiatan kolase dapat membantu meningkatkan kreativitas anak. Melalui kegiatan kolase, anak-anak merasa lebih tertarik untuk menciptakan hasil karya dengan berbagai bentuk yang diciptakan sesuai dengan imajinasinya sehingga kreativitas anak dapat meningkat dan berkembang sesuai harapan. 


\section{SIMPULAN}

Keterampilan kolase ialah suatu kegiatan yang membuahkan sebuah karya yang menggunakan bermacam-macam bahan seperti potongan-potongan, batuanbatuan, kaca berwarna, porselin, dan bahan dasar lainnya yang mampu dipadukan satu sama lain.

Kreativitas anak usia dini merupakan kreativitas yang dimiliki seseorang anak usia dini yang berbentuk aktivitas imajinatif dan kemampuan membuat perencaanperencanaan yang mampu menyelesaikan masalah yang ada dengan mengembangkannya atau lebih inovatif.

Kegiatan kolase dapat membantu meningkatkan kreativitas anak. Melalui kegiatan kolase, anak-anak merasa lebih tertarik untuk menciptakan hasil karya dengan berbagai bentuk yang diciptakan sesuai dengan imajinasinya sehingga kreativitas anak dapat meningkat dan berkembang sesuai harapan.

\section{DAFTAR PUSTAKA}

Hajar P., dan Evan S. (2010). Seni Keterampilan Anak. Yogyakarta: Universitas Terbuka.

Handayani, S., Sumarno, S., \& Suharno, Y. (2018). Pengaruh Aktivitas Kolase Terhadap Keterampilan Motorik Halus Pada Anak Usia Dini Melalui Metode Bermain Di Tk Pembina Kabupaten Rembang. Seuneubok Lada, 5(1), 38-53.

Rachmawati, Y, dan Euis K. (2011). Strategi Pengembangan Kreativitas Pada Anak. Jakarta : Kencana.

Sari, D. R., Suratman, A., \& Yulidesni, Y.(2014). Meningkatkan Kreativitas Seni Anak Melalui Teknik Kolase Dengan Media Serutan Pensil Pada Anak Paud Tunas Bangsa Kelompok B Desa Merambung Kecamatan Ulu Manna Kabupaten Bengkulu Selatan. (Doctoral dissertation, Universitas Bengkulu).

Sunarto. (2008). Perkembangan Pesertadidik. Jakarta: PT Reneka Cipta

Sumanto. (2006). Pengembangan Kreatifitas Seni Rupa Anak Sekolah Dasar.Jakarta: Depdiknas.

Tommy, S. (2009). Pengantar Teori dan Manajemen Komunikasi. Yogyakarta : MedPress.

Utami, M. (2005). Kreativitas dan Keberbakatan. Jakarta: Gramedia Pustaka Utama.

Yohana, E.(2013). Meningkatkan Kreativitas Anak dengan Teknik Mozaik Dengan Media Biji-bijian. Bengkulu: UNIB

Rachmawati, Y. \& Euis Kurniati. (2005). Strategi Pengembangan Kreativitas Pada Anak Usia Taman Kanak Kanak. Jakarta: Departemen Pendidikan Nasional, Direktorat Jendral Pendidikan Tinggi, Direktorat Pembinaan Pendidikan Tenaga Kependidikan dan Ketenagaan Perguruan Tinggi.

Wasih. (2007). Cara Mengembangkan Keterampilan Berkomonikasi dan Berbahasa pada Anak Peraskolah. Jakarta: PT Indeks 